\title{
An Integrated Analysis for Post Hydraulic Fracturing Production Forecast in Conventional Oil Sand Reservoir
}

Dedy Kristanto ${ }^{1 *}$, IMD Saputra Jagadita ${ }^{1}$

${ }^{1}$ Petroleum Engineering Department, Faculty of Mineral Technology, Universitas Pembangunan Nasional "Veteran" Yogyakarta, Jl. Padjajaran 104 (Lingkar Utara) Condongcatur, D.I. Yogyakarta, Indonesia - 55283

*Corresponding Author: dedykris.upn@gmail.com

\begin{tabular}{|c|c|}
\hline Article History: & Abstract \\
\hline $\begin{array}{l}\text { Received: May 11, } 2020 \\
\text { Receive in Revised Form: June 12, } 2020 \\
\text { Accepted: June 12, } 2020\end{array}$ & \multirow[b]{3}{*}{$\begin{array}{l}\text { Hydraulic fracturing is one of the stimulation treatment in oil and } \\
\text { gas well by creating a fractured through a proppant injection to the } \\
\text { formation. A most critical problem in the actual oil and gas industry } \\
\text { is that the fracturing engineers could not forecast approximately } \\
\text { post-production performance after fracturing the job, which is a } \\
\text { severe problem. This problem phenomenon has occurred in some } \\
\text { cases and significantly impacts production such as oversizing or } \\
\text { lower sizing of pumping rate setting. Integrated analysis for post job } \\
\text { hydraulic fracturing production based on the geometry model } \\
\text { iteration and Productivity Index (PI) comparison in the } \\
\text { conventional oil sand reservoir is simply a method to analyze and } \\
\text { forecast approximately incremental production performance. The } \\
\text { fractured software generates a fractured geometry model that } \\
\text { considers half-length of fractured parameters, width in front of } \\
\text { perforation, average width, fractured height, and pressure net. Then } \\
\text { we compare the Productivity Index's prediction value through the } \\
\text { method of Cinco-Ley, Samaniego and Dominguez. A case study in } \\
\text { the well of TM\#2 (conventional oil sand reservoir) was conducted } \\
\text { as the comprehensive study to provide the data and proceed analysis } \\
\text { for production forecast. We found that the geometry model and } \\
\text { iteration of PKN 2D method generated a small fractured geometry } \\
\text { model compare to fracCADE software. The cooperation between } \\
\text { PKN 2D method and Cinco-Ley, Samaniego, and Dominguez } \\
\text { concept successfully predict post-production forecast. This concept } \\
\text { could be proposed as a quick look measurement for production } \\
\text { scenarios to overcome pump sizing. }\end{array}$} \\
\hline Keywords: & \\
\hline $\begin{array}{l}\text { Integrated Analysis, Hydraulic Fracturing, } \\
\text { Production Forecast }\end{array}$ & \\
\hline
\end{tabular}

\section{INTRODUCTION}

Hydraulic fracturing is a stimulation treatment in oil and gas by creating fractures through a proppant injection to the formation. A most critical problem in actual oil and gas industry is the fracturing engineers could not forecasting approximately post-production performance after fracturing job, consequently the severe problem (Ghosh et al., 2019; Liu et al., 2013). This problem phenomenon has occurred in some cases and significantly impacts production, such as oversizing or lower pumping rate settings (Montgomery \& Smith, 2010). The decision to execute hydraulic fracturing in the oil sand reservoir based on the depletion of production performance history. Before hydraulic fracturing, the average oil rate was about 200-230 BOPD. However, the trend of production indicated that the production would decrease incisively. Another treatment has also been proposed for this formation with the mixed result, mainly by using thermal (Afdhol et al., 2020; Ferizal et al., 2013; Hidayat \& Abdurrahman, 2018; Kusumastuti et al., 2019; Melysa, 2016). Based on this situation, the hydraulic fracturing option is the correct decision to increase production performance and do skin by-pass in the well target.

This paper presented a study case to enrich the concept and directly illustrate a calculation revealed in this paper. This paper's principal objective is to demonstrate and introduce and show an idea widely about the simple concept of geometry model iteration and productivity index (PI) comparison in a conventional sand oil reservoir. This method analyses and forecasts approximately the incremental production performance (PI) and overtake a pump sizing problem that commonly occurs. 


\section{MATERIALS AND METHODOLOGY}

Hydraulic fracturing was done on well TM\#2. Well TM\#2 is located in Bekasap Formation in Basin of Middle Sumatera. The reservoir has the characteristic such as dominated by sandstone formation, which has the average reservoir temperature in $200-230^{\circ} \mathrm{F}$, the reservoir pressure is $868 \mathrm{psig}$, mid perforation in $5,532.5 \mathrm{ft}$, bubble point pressure is $80 \mathrm{psig}$, API oil in 33 , oil viscosity in $3.4 \mathrm{cp}$ and formation volume factor of oil (Bo) in $1.15 \mathrm{bbl} / \mathrm{STB}$.

The comprehensive step of hydraulic fracturing execution in TM\#2 was successfully done. It consists of several stages: injectivity test, mini fall-off test, step down test, mini frac, and main frac. Each test has a specific purpose and related to each other. After those tests were successfully done, we can proceed with the production forecasting after fracturing. Several data are required to support and proceed with the calculation such as geomechanics properties, fractured geometry data, fractured fluid properties, injection rate, and formation properties. PKN 2D method was the concept used for the fractured model approximation (Xf >Hf) (Kovalyshen \& Detournay, 2010; Rahman \& Rahman, 2010). After the error value less than 0.0001 , the geometry value from iteration could calculate the PI prediction and compare it by software geometry result.

The decision of execution hydraulic fracturing in TM\#2 well based on the depletion of production performance history. Execution of hydraulic fracturing in TM\#2 was conducted to design and accomplished the following test:

1. Injectivity Test

This test's main purposes is predicting the capability of formation to be fractured through an injection of frac fluid. This test completed by KCL $2 \%$ added by water. The result of the injectivity test shown in Figure 1. This test gives parameters as follows: Surface ISIP $=1,848$ psi; Treating Pressure Break $=2,600$ psi. According to Economides \& Nolte (2000), Instantaneous shut-in pressure (ISIP) is the bottom hole injection pressure immediately after the pump has been shut down. The effect of all the fluid friction-based pressure losses. Treating pressure break is the value where the pressure break formation in stable rate injection.

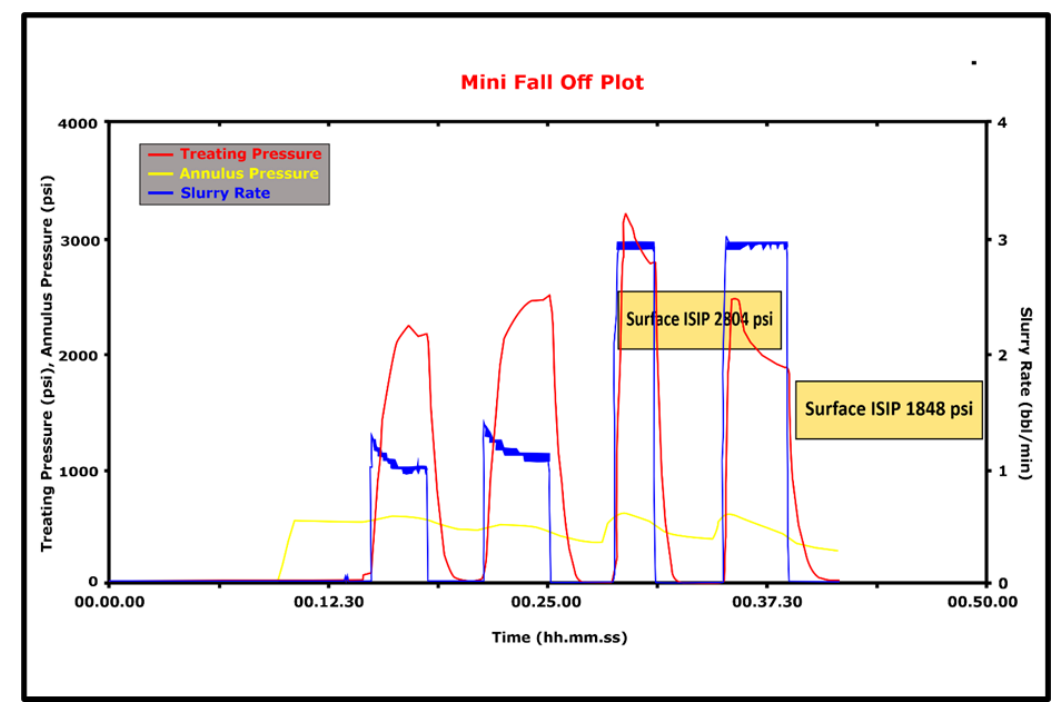

Figure 1. Well TM\#2 Injectivity Test

2. Mini fall-off Test

This test is still related to the previous test. The main objective of this test is to predict the transmissibility. This test was conducted by analysis of pressure depletion behaviour. Transimibility is the formation's ability to flow the fluids in certain thickness formation and certain viscosity. Besides those, two additional information could be reached from this test: closure pressure and fracture gradient. Closure pressure is defined as the fluid pressure at which an existing fracture globally closes, and the fracture gradient is defined as the gradient where the fractured could propagate. The test shown in Figure 2 and the result are as follows: Closure pressure $=3720 \mathrm{psi}$; Fracture gradient $=0.72 \mathrm{psi} / \mathrm{ft}$; Transimibility $=350.14 \mathrm{mD}$ $\mathrm{ft} / \mathrm{cp}$. 


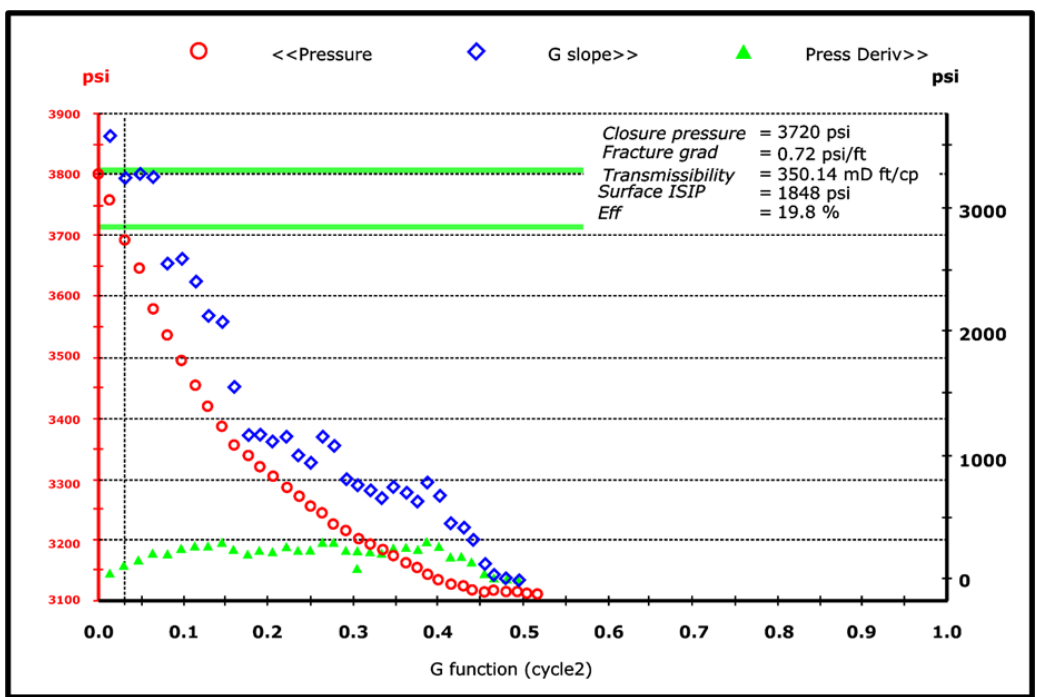

Figure 2. Well TM\#2 Mini Fall-off Analysis

3. Step-Rate Test

This test consists of two parts, the first one when pressure gradually increases at a specific rate against time named step (up) rate test. This test run by injection of KCL $2 \%$ added water. Another one when pressure decreases gradually against time, called step down test. The step rest test has an objective to predict the fracture extension rate and fracture extension pressure. Fracture extension rate is defined as the rate level that makes fractured propagate, and for fracture extension pressure is defined as the pressure level that makes fractured propagate. Another information that could be gained from this test is to validate closure pressure. For the step-down test, the data collected are analysis perforation friction, tortuosity, and total near-wellbore friction. After the test was conducted and the total near-wellbore pressure plotting against rate, the graph is indicating dominant tortuosity effect. Figure 3 shows the step rate test result. Figure 4 illustrate the plot for domination or perforation effect. The result of this test generate information as follows:

$\begin{array}{lll}\text { - } & \text { Frac extension rate } & =3.2 \mathrm{bpm} \\ \text { - } \quad \text { Fac extension pressure } & =3792 \mathrm{psi} \\ \text { - } \quad \text { Perforation friction } & =3639 \mathrm{psi} \\ \text { - } \quad \text { Tortuosity } & =350 \mathrm{psi} \\ \text { - Total Near Well Bore Fric } & =1300 \mathrm{psi} \\ & =1650 \mathrm{psi}\end{array}$

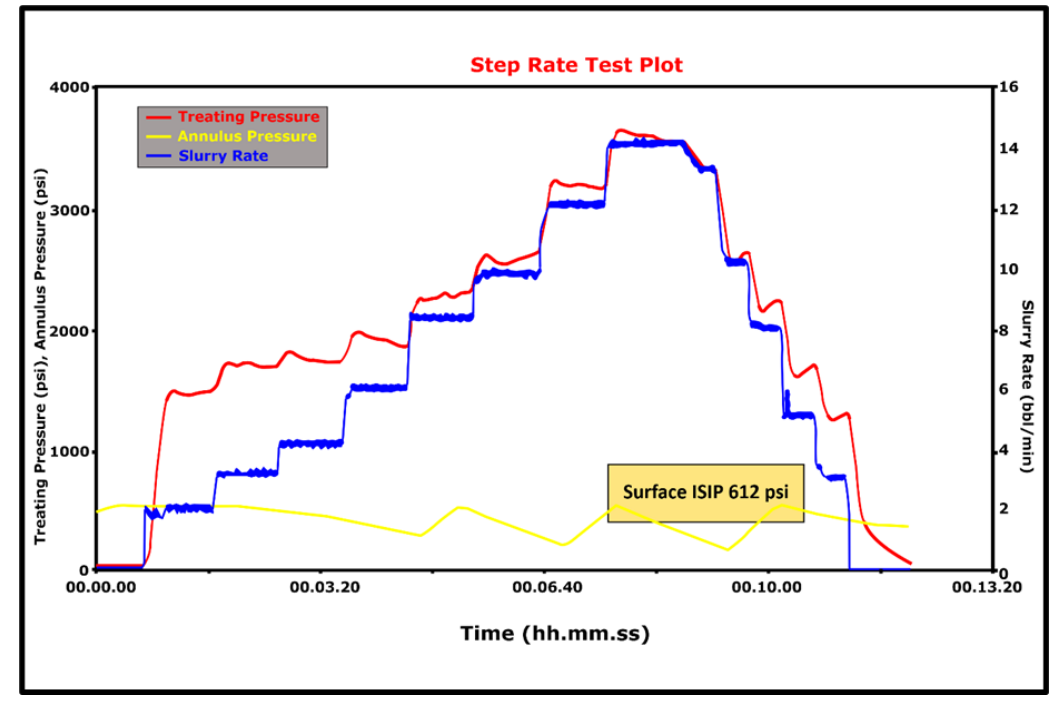

Figure 3. Well TM\#2 Step Rate Test 


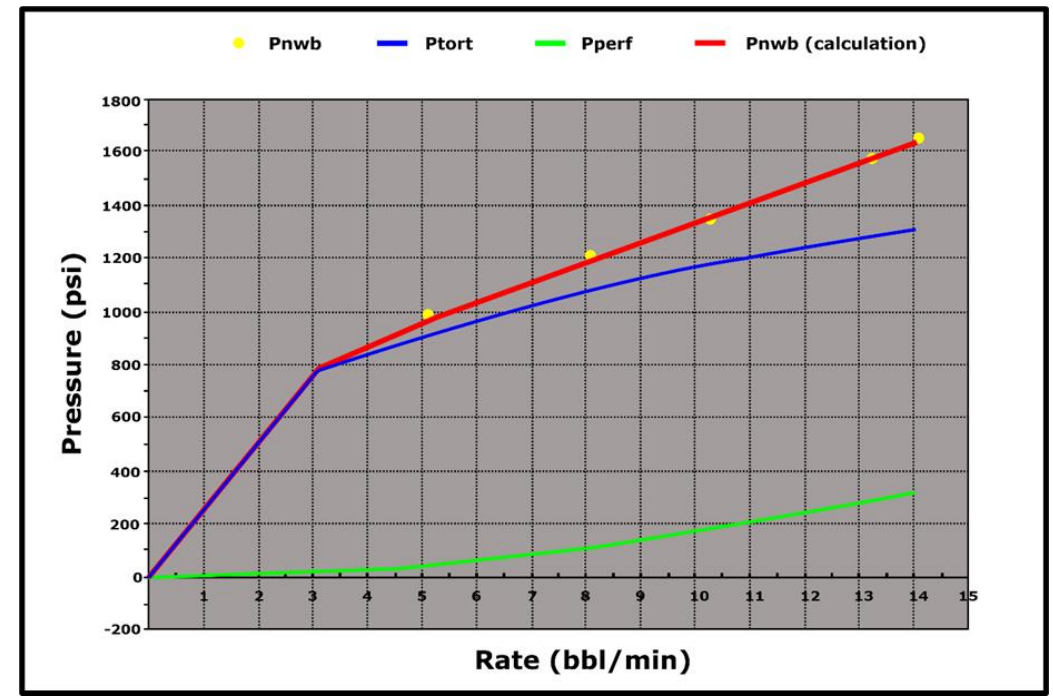

Figure 4. Well TM\#2 Analysis for Near Well Bore Effect

4. Mini Frac Test

This test's primary purposes are to make a small scale fractured model before executing the real main fracture. This test was conducted by using fluid fracture named YF-130 HTD. From this test, fracture engineers can make the scenario pad design for main fracturing input data. The graph of this test could be seen in Figure 5 and for the result as follows:

$$
\begin{aligned}
\text { - Closure pressure } & =2349 \mathrm{psi} \\
\text { - Frac gradient } & =0.46 \mathrm{psi} / \mathrm{ft} \\
\text { - Leak off Coefficient } & =5 \mathrm{E}-3 \mathrm{ft} / \mathrm{min}^{\wedge} 0.5 \\
\text { - Efficiency } & =19.8 \% \\
\text { - Net pressure } & =485 \mathrm{psi}
\end{aligned}
$$

Leak off coefficient is defined as the value of how much the effectiveness fracture fluid could make a fractured in formation. The efficiency is defined as the comparison between volume fluid injection to the total volume of fracture. Net pressure is defined as the fracturing fluid's excess pressure inside the fracture, above that required to keep the fractured open (Faisal, 2015), and for the design pad scenario and final pad scenario attached in Appendix-1. The graph result of mini frac shown in Figure 5.

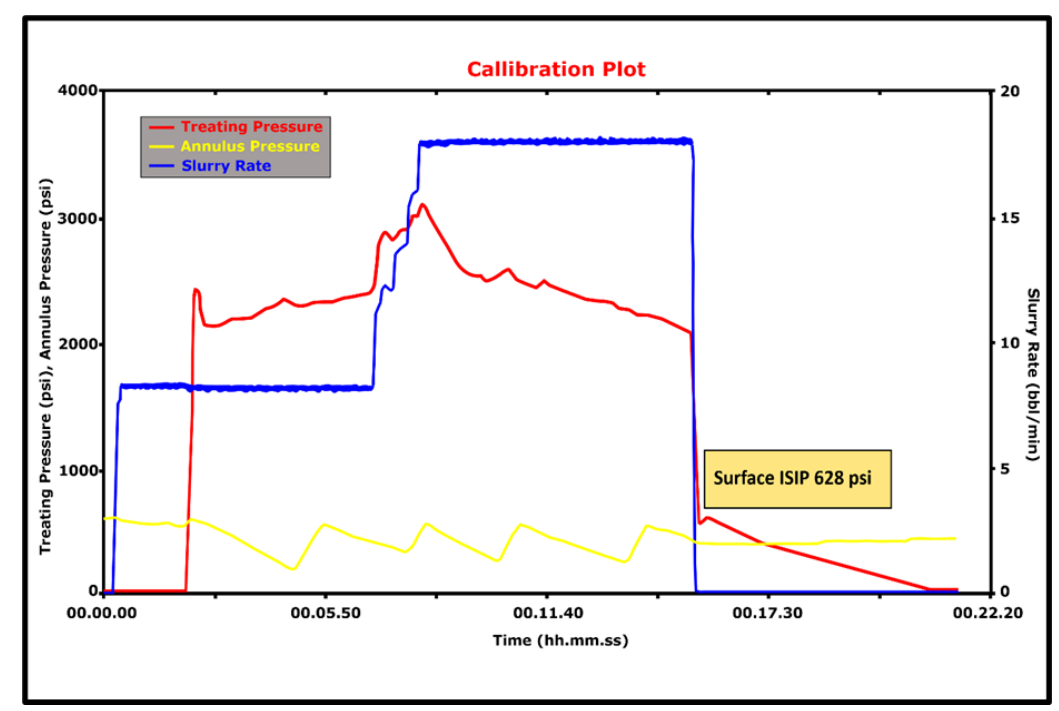

Figure 5. Well TM\#2 Mini Frac Test

\section{Main Frac}

After all of the data have been collected, and several parameters have been analysed, we could conduct a main frac. In this execution, the frac fluid that was used called YF 130 HTD. For proppant size 20/40 Carbolite and 12/18 Bauxite have been pumped in this step. The 20/40 Carbolite pumped firstly, then continued by $12 / 18$ Bauxite in order to avoid flow back proppant. During this operation, annulus pressure was maintained continuously at 250-500 psi to balance the differential injection pressure. This test's graph 
could be seen in Figure 6, and the geometry profile shown in Figure 7. Geometry fractured sized that generated as follows:

- Fractured height $(\mathrm{Hf}) \quad=32.85 \mathrm{~m} \quad=107.8 \mathrm{ft}$

- Half Length $(\mathrm{Xf}) \quad=80.19 \mathrm{~m} \quad=263.1 \mathrm{ft}$

- Average Width $(\bar{w}) \quad=0.002794 \mathrm{~m}=0.11$ inch

- Frac Conductivity (Wkf) $=2108.3 \mathrm{mD}-\mathrm{m}=6917 \mathrm{mD}-\mathrm{ft}$

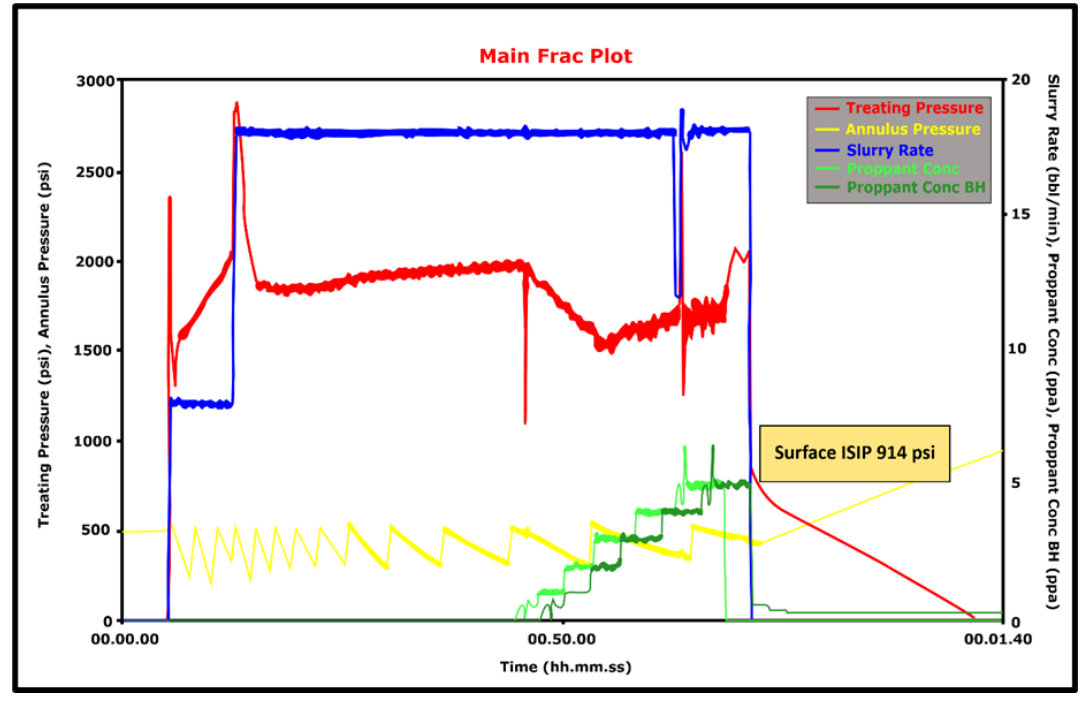

Figure 6. Well TM\#2 Main Frac Execution

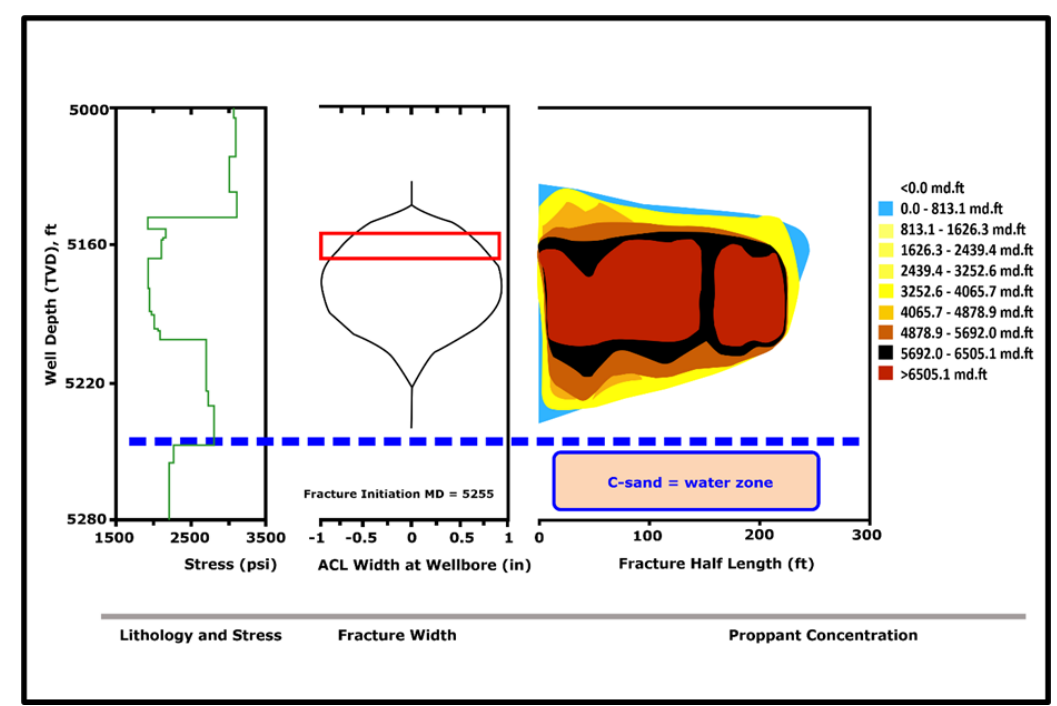

Figure 7. Well TM\#2 Geometry Profile against Wkf

\section{RESULTS AND DISCUSSION}

The geometry model iteration aims to generate a secondary geometry profile mathematically. The model used in the calculation is PKN 2D model (Due to Xf $>\mathrm{Hf}$ ). If $\mathrm{Xf}<\mathrm{Hf}$, we use the KGD 2D model to calculate (Economides at al., 1990). Then we could compare the geometry from software fracCADE 3D to PKN 2D model, and finally proceeding it to PI (Productivity Index) comparison by Method Cinco-Lee, Samaniego, and Dominguez in order for production forecasting. Several data mentioned in the post job report (attached in Appendix-2) require the calculation proceeding, as mentioned in Table 1 and Table 2, respectively.

Table 1. Data Input for Geometry Model Iteration

\begin{tabular}{ccc}
\hline Parameter Data & Field Unit & Conversion \\
\hline Young Modulus (E) & $1,729,000 \mathrm{psi}$ & - \\
Poisson Ratio & 0.25 & -
\end{tabular}


An Integrated Analysis for Post Hydraulic Fracturing Production Forecast in Conventional Oil Sand Reservoir (Dedy Kristanto, IDM Saputra Jagadita)

\begin{tabular}{ccc} 
n' base gel & 0.4 & - \\
K' base gel & 0.35 & - \\
Rate injection $\left(\mathrm{q}_{\mathrm{i}}\right)$ & $18 \mathrm{bpm}$ & $0.046 \mathrm{~m}^{3} /$ second \\
Total treatment time $\left(\mathrm{T}_{\mathrm{t}}\right)$ & $72 \mathrm{~min}$ & 4320 second \\
Spurt loss $\left(\mathrm{S}_{\mathrm{p}}\right)$ & $0 \mathrm{gal} / 100 \mathrm{ft}^{2}$ & $0 \mathrm{~m}^{3} / \mathrm{m}^{2}$ \\
Coeff. Leak-off total $\left(\mathrm{C}_{\mathrm{L}}\right)$ & $0.0035 \mathrm{ft} / \sqrt{\mathrm{min}}$ & $\begin{array}{c}0.0001377 \\
\mathrm{~m} / V_{\mathrm{sec}}\end{array}$ \\
\hline
\end{tabular}

Table 2. Geometry Properties Comparison

\begin{tabular}{cccc}
\hline \multirow{2}{*}{ Parameters } & \multirow{2}{*}{ Unit } & \multicolumn{2}{c}{ Well TM\#2 } \\
& Design & Actual \\
\hline Half Length $\left(\mathrm{x}_{\mathrm{f}}\right)$ & $\mathrm{m}$ & 49.07 & 80.19 \\
Average Width $(\bar{w})$ & $\mathrm{m}$ & 0.00731 & 0.002794 \\
Fractured Height $\left(\mathrm{h}_{\mathrm{f}}\right)$ & $\mathrm{m}$ & 38.1 & 32.85 \\
\hline
\end{tabular}

The following step of the geometry model iteration calculation are:

1. Calculating Plain Strain Modulus (E') as below:

$$
\begin{aligned}
& E^{\prime}=\frac{E}{(1-v)^{2}} \\
& =\frac{1729000}{(1-0,25)^{2}} \\
& =1,844,266.66 \mathrm{psi}
\end{aligned}
$$

2. Determining the start for iteration. The value of $\left(\mathrm{X}_{\mathrm{f} \text { (iteration) })}\right)=49.07 \mathrm{~m}$. This value is used to be start point in the case could penetrate the interest zone as far as $49.07 \mathrm{~m}$.

3. Calculate the width in front of perforation $\left(\mathrm{w}_{(0)}\right)$ through:

$$
\begin{aligned}
& W_{0}=9.15^{\frac{1}{\left(2 n^{\prime}+2\right)}} x 3.98^{\frac{n}{\left(2 n^{\prime}+2\right)}}\left[\frac{1+2.14 n^{\prime}}{n^{\prime}}\right]^{\frac{n}{\left(2 n^{\prime}+2\right)}} x K^{\prime} \frac{1}{\left(2 n^{\prime}+2\right)}\left[\frac{q^{i} h_{f}^{\left(1-n^{\prime}\right)}}{E}\right]^{\frac{1}{2\left(2 n^{\prime}+2\right)}} \\
& =9.15^{\frac{1}{(2(0.4)+2)}} \times 3.98^{\frac{0.4}{(2(0.4)+2)}}\left[\frac{1+2.14(0.4)}{0.4}\right]^{\frac{0.4}{(2(0.4)+2)}} \\
& \times 0.3515^{\frac{1}{(2(0.4)+2)}}\left[\frac{0.18^{0.4} \times 38.1^{(1-0.64)} \times 49.07}{3,730,689.141}\right]^{\frac{1}{(2(0.4)+2)}} \\
& =0.063212135 \mathrm{~m}
\end{aligned}
$$

4. Calculate the average width $(\bar{w})$ through as below:

$$
\begin{aligned}
& \bar{W}=\frac{\pi}{5} W_{0} \\
& \bar{W}=\frac{\pi}{5} x 0.063212135=0.039697221 \mathrm{~m}
\end{aligned}
$$

5. Calculate the value of $\beta$ through the equation as below:

$$
\begin{aligned}
& \beta=\frac{2 C_{L} \sqrt{\pi t}}{\bar{W}+2 s_{P}} \\
& =\frac{2(0.0001377) \sqrt{(3.14)(4320)}}{(0.039697221)+2(0)} \\
& =0.807998453
\end{aligned}
$$

Through Table 4 in Appendix-3 for $\beta=0.807998453$ The value for

$$
\begin{aligned}
& {\left[\exp \left(\beta^{2}\right) \operatorname{erfc}(\beta)\right]+\frac{2 \beta}{\sqrt{\pi}}-1} \\
& =0.383753
\end{aligned}
$$


6. Calculate $\mathrm{X}_{\mathrm{f}(\text { iteration }+1)}$ through equation as below:

$$
\begin{aligned}
& x_{f}=\frac{\left(\bar{w}+2 S_{P}\right) q i}{4 \pi h_{f} c \frac{2}{L}}\left[\exp \left(\beta^{2}\right) \operatorname{erfc}(\beta)+\frac{2 \beta}{\sqrt{\pi}}-1\right] \\
& \frac{(0.039697221+2(0))(0.046)}{4(3.14)(38.1)(0.0001377)^{2}}(0.383753) \\
& =77.23 \mathrm{~m}
\end{aligned}
$$

Calculate the error value through as below:

Error $=\mathrm{X}_{\mathrm{f}(\text { iteration }+1)}-\mathrm{X}_{\mathrm{f}(\text { iteration })}$

$=77.23-49.07$

$=28.16$

If the error value $>0,0001$, the calculation must repeat with the value of $\mathrm{X}_{\mathrm{f}(\text { iteration }+1)}$ to be plot as $\mathrm{X}_{\mathrm{f}(\text { iteration }) \text {. }}$ Theses process continually proceed until reach error value $\leq 0,0001$ (Annas, 2005). 'The table of iteration and trial-error process of PKN 2D for Well TM\#2 is attached in Appendix-4. The final result of geometry model iteration are mentioned as below:

- Half Length $\left(\mathrm{X}_{\mathrm{f}}\right)=69.957 \mathrm{~m}=229.516 \mathrm{ft}$

- Width in front of perforation $\mathrm{w}_{(0)}=0.072 \mathrm{~m}=2.824$ inch

- Average width $(\bar{w})=0.045 \mathrm{~m}=1.774$ inch

- Fractured height $\left(\mathrm{h}_{\mathrm{f}}\right)=38.1 \mathrm{~m}=125 \mathrm{ft}$ (software)

- Calculate $P_{\text {net }}$ through equation as below:

$$
\begin{aligned}
& P_{n e t}=\Delta P_{f}=\frac{E^{\prime}\left(w_{(0)}\right)}{2 \mathrm{hf}} \\
& =\frac{(1,844,266.67)(0.072)}{2(38.1)} \\
& =1736.5 \mathrm{psi}
\end{aligned}
$$

The final comparison of geometry properties through three results consisting of Design, Actual, and PKN 2D Method is mentioned in Table 3.

Table 3. Final Geometry Properties Comparison (Design, Actual, and PKN 2D Method)

\begin{tabular}{ccccc}
\hline Parameter & Unit & & Well TM\#2 & \\
& & Design & Actual & PKN 2D \\
\hline Half Length $\left(\mathrm{x}_{\mathrm{f}}\right)$ & $\mathrm{m}$ & 49.07 & 80.19 & 69.95 \\
Average Width $(\bar{w})$ & $\mathrm{m}$ & 0.00731 & 0.00279 & 0.045057 \\
$\begin{array}{c}\text { Fractured Height } \\
\left(\mathrm{h}_{\mathrm{f}}\right)\end{array}$ & $\mathrm{m}$ & 38.1 & 32.85 & 38.1 \\
\hline
\end{tabular}

\section{Productivity Index (PI) Prediction Comparison}

Productivity Index (PI) is the index value to classified the capability of formation to produce the fluid. Based on the theory, the PI will incisively increase after hydraulic fracturing due to the increase of fractured permeability, fracture well radius (rw'), and skin by-pass impact on the reservoir (see Figure 8). 


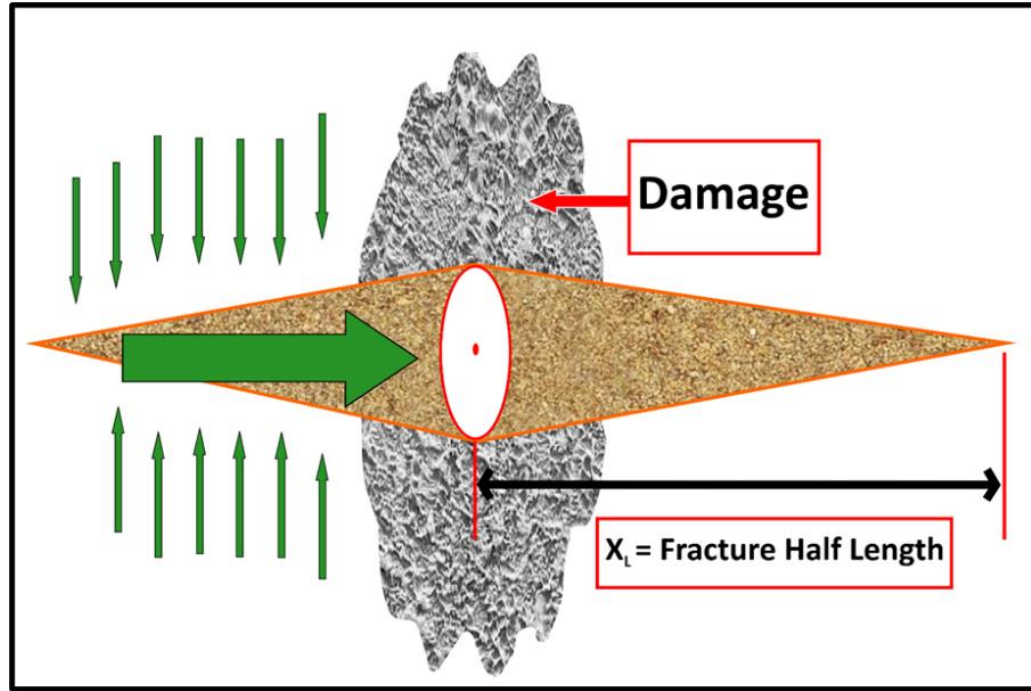

Figure 8. Schematic Fractured Model in Reservoir

The following step will provide the calculation of comparison PI (J/Jo) before and after fracturing using Cinco-Ley, Samaniego and Dominguez. Then will be followed by IPR Calculation. The data that requires proceeding with the calculation will be mentioned in Table 4 and Table 5.

Table 4. Input Data for PI Prediction Comparison

\begin{tabular}{ccc}
\hline Parameter & Unit & Well TM\#2 \\
\hline Fractured Conductivity, (Wkf) & $\mathrm{mD} . \mathrm{ft}$ & 6917 \\
Initial permeability, (ki) & $\mathrm{mD}$ & 30 \\
Actual Half Length Frac, (Xf) & $\mathrm{ft}$ & 263.1 \\
Drainage Radius, (re) & $\mathrm{ft}$ & 570 \\
Well Radius, (rw) & $\mathrm{ft}$ & 0.3 \\
\hline
\end{tabular}

Table 5. Production Data for IPR Calculation

\begin{tabular}{ccc}
\hline \multirow{2}{*}{ Production Data } & \multicolumn{2}{c}{ Well TM\#2 } \\
& Before HF & After HF \\
\hline Fluid Rate (QL),BFPD & 160 & 430 \\
Oil Rate (Qo test), BOPD & 155.74 & 401.62 \\
Water Rate (Qw), BWPD & 4.25 & 28.38 \\
Gas Rate (Qg), MSCF & 0 & 0 \\
Water cut (WC), \% & 2.66 & 6.66 \\
Reservoir Pressure (Pr), psig & 818 & 818 \\
BHP (Pwf test), psi & 110 & 150 \\
Bubble Point Pressure (Pb), & 80 & 80 \\
psig & 1.15 & 1.15 \\
Bo, (BBL/STB) & 3.4 & 3.4 \\
$\mu o$, cp & & \\
\hline
\end{tabular}

The following step of the PI prediction calculation is:

1. Fractured Conductivity (Fcd) Calculation

Fractured conductivity (Fcd) is simply defined as the value of how the capability level to flow fluid in fractured. The calculation as below: 


$$
\begin{aligned}
& F c d=\frac{W k f}{k i x X f} \\
& =\frac{6917}{30 \times 263.1} \\
& =0.8763
\end{aligned}
$$

Then find the effective well radius ( $\left.\mathrm{rw}^{\prime}\right)$ by making an intersection perpendicularly in line $\mathrm{X}$ for Fcd towards line Y for rw'/Xf through Cinco-Ley, Samaniego Dominguez chart as shown in Figure 9. From the chart, we have the value for $\mathrm{rw}^{\prime} / \mathrm{Xf}$ is 0.19 .

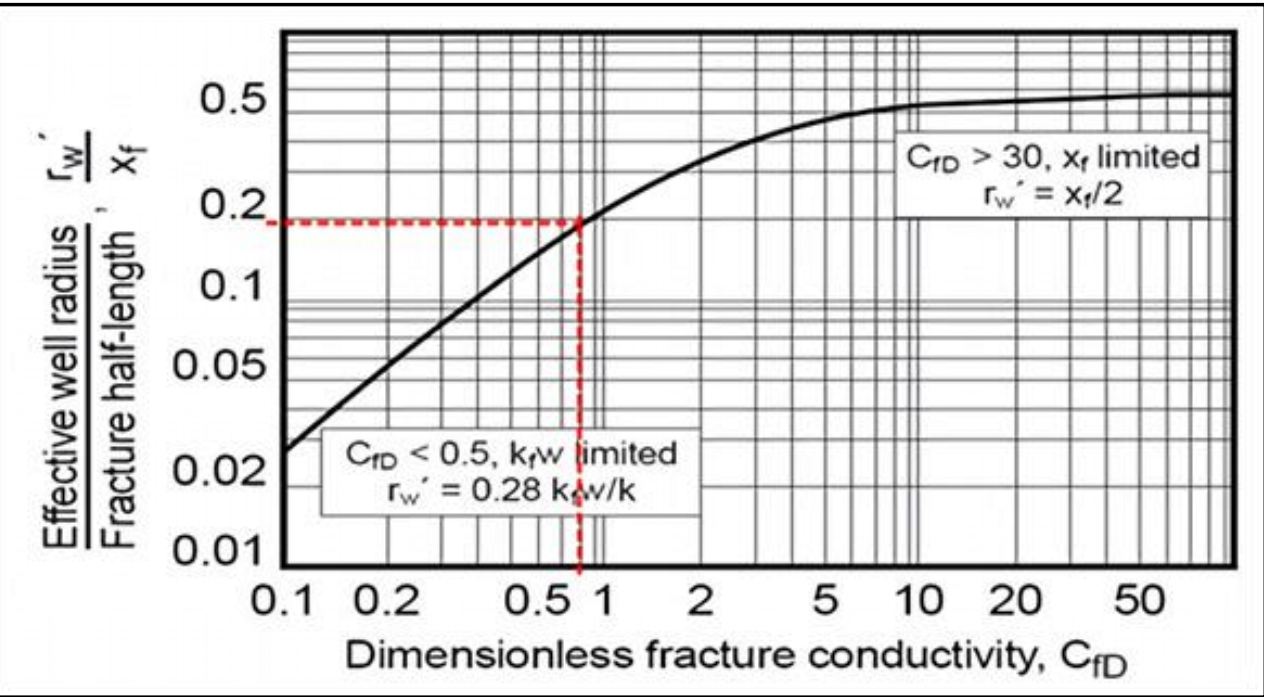

Figure 9. Chart for Fcd vs rw'/Xf plot

2. The calculation for Comparison of J/Jo (=Initial PI/ Frac PI)

a. Based on Actual Fractured (Software FracCADE 3D)

Based on chart where rw' $=0.19 \times \mathrm{Xf}$

where the actual fractured for $\mathrm{Xf}=263.1 \mathrm{ft}$

Then rw' $=0.19 \times 263.1 \mathrm{ft}=49.98 \mathrm{ft}$

Where

$J / J o=\frac{\ln (r e / r w)}{\ln \left(r e / r w^{\prime}\right)}$

$=\frac{\ln (570 / 0.3)}{\ln (570 / 49.98)}$

$=3.10$

b. Based on PKN 2D Method

Based on chart where rw' $=0.19 \times \mathrm{Xf}$

where the PKN 2D for Xf $=229.516 \mathrm{ft}=69.95 \mathrm{~m}$

Then rw' $=0.19 \times 229.516 \mathrm{ft}=43.60 \mathrm{ft}$

Where

$J / J o=\frac{\ln (570 / 0.3)}{\ln (570 / 43.60)}$

$=2.93$

c. Based on Production History

Where

$$
\begin{aligned}
& J / J o=\frac{\text { PIafter }}{\text { PIbefore }} \\
& =\frac{Q f /(\text { Ps }- \text { Pwf }) \text { after }}{Q f /(P s-P w f) \text { before }}
\end{aligned}
$$




$$
\begin{aligned}
& =\frac{430 /(818-150)}{160 /(818-11)} \\
& =2.85
\end{aligned}
$$

\section{Inflow Performance Relationship (IPR) Calculation}

Inflow performance relationship (IPR) is curved, expressing how the formation capability to produce fluid through the relationship between the rate of production against bottom hole pressure. The method used in this calculation is the Standing-Harrison method that considers skin and flows efficiency (FE)(Beggs, 1991). The calculation step regarding the IPR calculation on TM\#2 as follows:

\section{IPR Before Fracturing (Standing's Method)}

1. Calculate skin factor (Darcy Equation)

$$
\begin{aligned}
& Q o=\frac{0,00708 \times k \times h \times(P r-P w f)}{\mu o \times B o \times \ln \left(\frac{r e}{r w}\right)+S} \\
& 155.74=\frac{0,00708 \times 30 \times 40 \times(818-110)}{3,4 \times 1,15 \times \ln \left(\frac{570}{0,3}\right)+S}
\end{aligned}
$$

$\mathrm{S}=9.1$ (indicated formation damaged)

2. Calculate FE (flow efficiency)

$$
\begin{aligned}
& F E=\frac{\ln \left(0.472 \times\left(\frac{r e}{r w}\right)\right)}{\ln \left(0.472 \times\left(\frac{r e}{r w}\right)\right)+S} \\
& =\frac{\ln \left(0.472 \times\left(\frac{570}{0.3}\right)\right)}{\left.\ln \left(0.472 \times\left(\frac{570}{0.3}\right)\right)+9.1\right)}=0.42
\end{aligned}
$$

3. Calculate Pwf' ( Pwf that affected by skin)

$$
\begin{aligned}
& P_{w f}{ }^{\prime}=P_{S}-\left(\left(P_{S}-P_{w f}\right) x F E\right) \\
& =818-((818-110) \times 0.427) \\
& =515.68 \mathrm{psig}
\end{aligned}
$$

4. Calculate $\mathrm{Qo} / \mathrm{Qmax} @ \mathrm{FE}=1$

$$
\begin{aligned}
& Q_{o} / Q_{\max _{F E=1}}=1-0.2\left(\frac{P w f^{\prime}}{P s}\right)-\left(\frac{P w f^{\prime}}{P S}\right)^{2} \\
& =1-0.2\left(\frac{516.68}{818}\right)-\left(\frac{516.68}{818}\right)^{2} \\
& =0.55 \text { bopd }
\end{aligned}
$$

5. Calculate $\mathrm{Qmax} @ \mathrm{FE}=1$

$$
\begin{aligned}
& \text { Qmax } @ F E=1=\frac{Q o}{Q o / Q \max F E=1} \\
& =\frac{155.74}{0.55}=279.79 \text { bopd }
\end{aligned}
$$

6. Calculate $\mathrm{Qmax} @ \mathrm{FE}=0.427$ in assumption of $\mathrm{Pwf}=0$ psig $\left(\mathrm{Pwf}^{\prime}=468.19 \mathrm{psig}\right)$

$$
\begin{aligned}
& Q_{o \max _{F E}=0.427}=Q_{\max _{F E=1}} x\left(1-0.2\left(\frac{P w f^{\prime}}{P S}\right)-\left(\frac{P w f^{\prime}}{P S}\right)^{2}\right) \\
& =279.9 x\left(1-0.2\left(\frac{468.19}{818}\right)-\left(\frac{468.19}{818}\right)^{2}\right)
\end{aligned}
$$


$=174.43$ bopd.

Therefore, make several assumptions toward pwf and pwf's value in the range of 0-818 psig, then calculated Qo.

\section{IPR After Fracturing (Harrison's Method)}

Harrison's IPR Method was a modification for Standing's IPR equation. This equation is appropriately used when the value of FE is highly positive, and Pwf' is negative(Wibowo, 2005). If we use Standing's IPR in this condition, it will generate an odd curve of IPR that is not a representative of IPR from well TM\#2. For the steps of calculation as below:

1. Calculate skin factor (Cinco-Ley, Samaniego \& Dominguez)

After fractured, the value of the skin is defined through:

Skin $=-\ln (\mathrm{rw} / \mathrm{rw})$

For the rw'(fractured $\mathrm{rw}$ ) is defined through:

$\mathrm{rw}=0.19 \times \mathrm{Xf}$

Where the 0.19 is obtained through Chart (Cinco-Ley, Samaniego \& Dominguez) in Figure 9 and for the $\mathrm{Xf}$ is obtained through iteration trial error PKN 2D above.

$\mathrm{rw}^{\prime}=0.19 \times 229.516 \mathrm{ft}$

$=25.86 \mathrm{ft}$

Then skin after $=-\ln (25.86 / 0.3)$

$=-4.45$ (Indicated stimulation or improvement)

2. Calculated Flow Efficiency (FE)

$$
\begin{aligned}
& F E=\frac{P r-P w f-\Delta P s}{\operatorname{Pr}-\mathrm{Pwf}} \\
& \Delta P_{S}=\frac{141.2 \times Q \times \text { Bo } \times \mu \mathrm{o}}{\mathrm{k} \times \mathrm{h}} \times S \\
& =\frac{141.2 \times 430 \times 1.15 \times 3.4}{30 \times 40} \times(-4.45) \\
& =-880.35
\end{aligned}
$$

Then, $F E=\frac{818-150-(-880.35)}{818-150}=2.31$

3. Calculate Pwf' (Pwf affected by skin)

$$
\begin{aligned}
& \text { Pwf'= Ps-((Ps-Pwf }) \times \text { FE })) \\
& =818-((818-150) \times 2.31) \\
& =-730.35 \mathrm{psig}
\end{aligned}
$$

4. Calculate Qo/Qmax $@ \mathrm{FE}=1$

$$
\begin{aligned}
& \mathrm{Qo} / \mathrm{Qmax} @ \mathrm{FE}=1=1.2-\left(0.2 \times \operatorname{EXP}\left(1.792 \times\left(\frac{P w f^{\prime}}{\mathrm{Ps}}\right)\right)\right. \\
& \begin{array}{c}
\left.=1.2-\left(0.2 \times \operatorname{EXP}\left(1.792 \times \frac{-730.35}{818}\right)\right)\right) \\
=1.15 \mathrm{bopd}
\end{array}
\end{aligned}
$$

5. Calculate $\mathrm{Qmax} @ \mathrm{FE}=1$

$\mathrm{Qmax} @ \mathrm{FE}=1=\frac{Q o}{\mathrm{Q} / \mathrm{Qmax} F E=1}$ 
$=\frac{401.62}{1.15}=346.33 \mathrm{bopd}$

6. Calculate $\mathrm{Qmax} @ \mathrm{FE}=2.31$ inassumption of $\mathrm{Pwf}=0$ psig $\left(\mathrm{Pwf}^{\prime}=-1078.03 \mathrm{psig}\right.$ )

$$
\begin{aligned}
& \begin{array}{l}
\mathrm{Q}_{\max } \mathrm{FE}=2.31=\mathrm{Q}_{\max \mathrm{FE}=1 \times 1} \times 1.2-(0.2 \times \operatorname{EXP}(1.792 \times 1 \\
\left.\left.\left(\frac{P w f^{\prime}}{\mathrm{Ps}}\right)\right)\right)
\end{array} \\
& =346.33 \times 1.2-\left(0.2 \times \operatorname{EXP}\left(1.792 \times\left(\frac{-1078.03}{818}\right)\right)\right) \\
& =409.07 \text { bopd. }
\end{aligned}
$$

Therefore, make several assumptions toward value of Pwf' in range of 0-818 psig, then calculated Qo. As the supporting evidence, will be shown the historical oil production as shown in Figure 10. For the IPR result shown in Table 6 and for IPR curve will be shown Figure 11.

Table 6. IPR Calculation

\begin{tabular}{ccccc}
\hline \multirow{2}{*}{ Pwf, psig } & \multicolumn{2}{c}{ Before Frac } & \multicolumn{2}{c}{ After Frac } \\
& Pwf', psig & Qo, bopd & Pwf', psig & Qo, bopd \\
\hline 0 & 468.20 & 174.44 & -1078.03 & 409.08 \\
50 & 489.58 & 166.12 & -962.14 & 407.19 \\
100 & 510.96 & 157.50 & -846.24 & 404.76 \\
150 & 532.34 & 148.58 & -730.35 & 401.62 \\
200 & 553.72 & 139.35 & -614.46 & 397.58 \\
250 & 575.11 & 129.81 & -498.56 & 392.37 \\
300 & 596.49 & 119.97 & -382.67 & 385.65 \\
350 & 617.87 & 109.82 & -266.77 & 376.99 \\
400 & 639.25 & 99.37 & -150.88 & 365.83 \\
450 & 660.63 & 88.61 & -34.98 & 351.45 \\
500 & 682.01 & 77.54 & 80.91 & 332.90 \\
550 & 703.39 & 66.17 & 196.81 & 309.00 \\
600 & 724.78 & 54.49 & 312.70 & 278.19 \\
650 & 746.16 & 42.51 & 428.59 & 238.47 \\
700 & 767.54 & 30.22 & 544.49 & 187.27 \\
750 & 788.92 & 17.62 & 660.38 & 121.28 \\
800 & 810.30 & 4.72 & 776.28 & 36.21 \\
818 & 818.00 & 0.00 & 818.00 & 0 \\
\hline
\end{tabular}




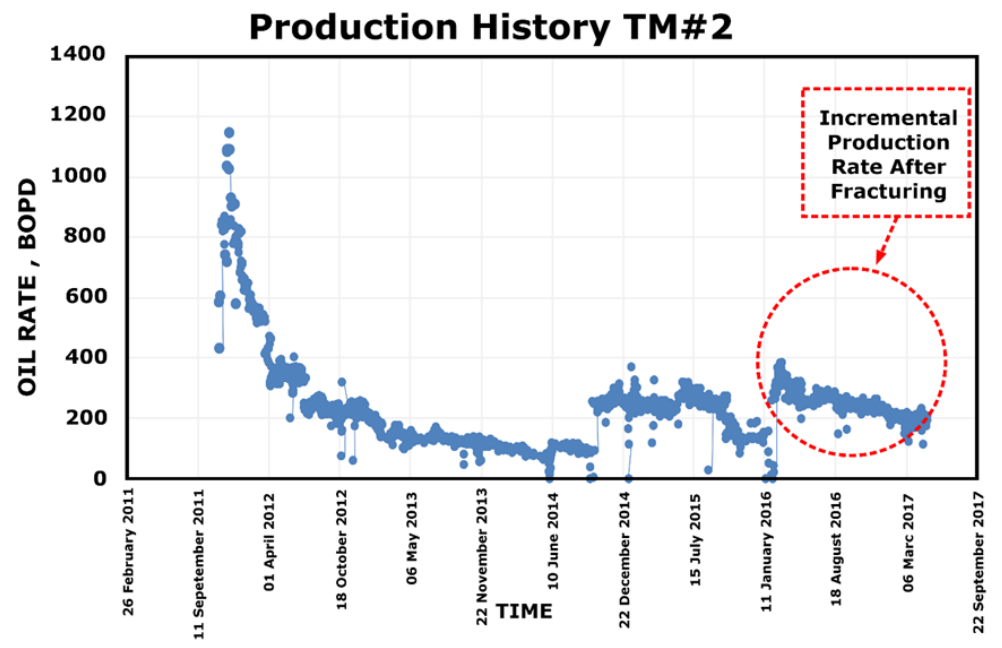

Figure 10. Production History of Well TM\#2

IPR WELL TM\# 2

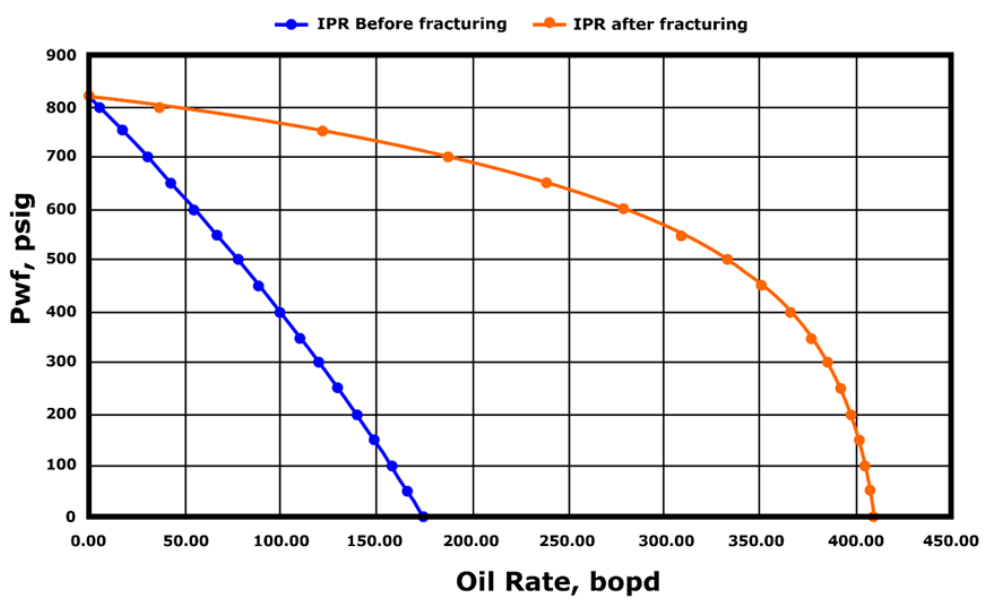

Figure 11. IPR Curve of Well TM\#2 Before and After Fracturing

Furthermore, this method is simply answering the problem that already happened in forecasting about how the value of incremental production after fracturing. The problem that commonly happening such as over sizing or lower sizing pump setting. The geometry model from PKN 2D tendency give a small geometry result than fracCADE 3D result. This is caused by the PKN 2D basically calculated based on mathematically concept, instead the fracCADE 3D calculated geometry model based on several considerations such as pressure behaviour, fluid properties, and reservoir properties. But the combination PKN 2D and Cinco-Ley, Samaniego \& Dominguez Chart's successfully accomplished the approximation value in order for forecasting production after fracturing based on this sample case. The trial error and iteration flow-step on PKN 2D calculation above start from value 49,07 m. This value is used to be start point in case could penetrate the interest zone as far as $49.07 \mathrm{~m}$. After reached error value less than 0.0001 the result are Half Length $\left(\mathrm{X}_{\mathrm{f}}\right)=69.95671953 \mathrm{~m}=229.516 \mathrm{ft}$. Width in front of perforation $\mathrm{w}_{(0)}=$ $0.071747 \mathrm{~m}=2.824$ inch. Average width $(\bar{w})=0.0450572 \mathrm{~m}=1.7739$ inch. Fractured height $\left(\mathrm{h}_{\mathrm{f}}\right)=38.1$ $\mathrm{m}=125 \mathrm{ft}$ (software result) and $\mathrm{P}_{\text {net }}=1736$ psi. $\mathrm{P}_{\text {net }}$ is defined as the pressure that make fluid available for propagating the fracture and producing width. The next step, find the effective well radius ( $\mathrm{rw}$ ') by make an intersection perpendicularly in line X for Fcd towards line Y for rw'/Xf through Cinco-Ley, Samaniego and Dominguez. From above chart, the value for $\mathrm{rw}^{\prime} / \mathrm{Xf}$ is 0.19 . Then this value proceeding to the calculation of J/Jo (PI after/before fracturing) comparison through the three concepts such from software, PKN 2D method, and the actual of production history data. From the three calculations we could see clearly that the result from J/Jo in PKN 2D method successfully reached the approximation PI comparison prediction from actual production data. This clearly stated this concept successfully applied. The next step is IPR curve using the Standing-Harrison equation. This IPR method, consider the skin factor and FE as 
the basic influence that impact to the production performance. As stated above, that hydraulic fracturing could be a best option for skin-bypass to improve the damaged zone in reservoir.

\section{CONCLUSIONS}

Geometry model and iteration of PKN 2D method generated a small fractured geometry model rather than software fracCADE modelling. This is caused the PKN 2D method just an approximation based on mathematically model without other consideration such as rock properties, pressure maintenance, and fluids properties behaviour. The cooperation between PKN 2D method and Cinco-Ley, Samaniego \& Dominguez concept successfully reached for the post hydraulic fracturing production forecast in case well TM\#2 by generated a closer result to PI comparison through actual production history. This concept could be appropriate to be used as a quick look measurement for production scenario in order to solve the problem in over sizing or lower sizing pump setting in artificial lift method.

\section{ACKNOWLEDGEMENT}

The authors would thank the Petroleum Engineering Department UPN "Veteran" Yogyakarta for the supports. We also fully acknowledge to Mr. Yudhi from Chevron Pacific Indonesia, Mr. Erlang from Baker Huges, and Mr. Faisal from Schlumberger for being a great supervision, discussion and the valuable knowledge in accomplished this paper

\section{REFERENCES}

Afdhol, M. K., Erfando, T., Hidayat, F., Hasibuan, M. Y., \& Regina, S. (2020). The Prospect of Electrical Enhanced Oil Recovery for Heavy Oil: A Review. Journal of Earth Energy Engineering, 8(2), 73-94. https://doi.org/10.25299/jeee.2019.4874

Annas, P. . (2005). Kerja Ulang Stimulasi-Hydraulic Fracturing. Jurusan Teknik Perminyakan, Universitas Pembangunan Nasional "Veteran" Yogyakarta, Indonesia.

Beggs, H. D. (1991). Production optimization using nodal analysis.

Economides at al. (1990). Reservoir Stimulation Handbook. Association of Environmental \& Engineering Geologists.

Economides, M. J., \& Nolte, K. G. (2000). Reservoir Stimulation (3rd ed.). Wiley.

Faisal, F. (2015). Post Job Report Hydraulic Fracturing Well X.

Ferizal, F. H., Netzhanova, A. A., Lee, J., Bae, W., Am, S., \& Gunadi, T. A. (2013, June 11). Revitalizing Indonesia's Potential for Oil Production: The Study of Electromagnetically Heated Gravel Packs for Steam-produced Heavy Oil Reservoirs. SPE Heavy Oil Conference-Canada. https://doi.org/10.2118/165508-MS

Ghosh, S., Busetti, S., \& Slatt, R. M. (2019). Analysis and prediction of stimulated reservoir volumes though hydraulic fracturing: Examples from western Arkoma Basin. Journal of Petroleum Science and Engineering, 182, 106338. https://doi.org/10.1016/j.petrol.2019.106338

Hidayat, F., \& Abdurrahman, M. (2018). A Prospective Method to Increase Oil Recovery in WaxyShallow Reservoir. IOP Conference Series: Materials Science and Engineering, 306(1). https://doi.org/10.1088/1757-899X/306/1/012040

Kovalyshen, Y., \& Detournay, E. (2010). A reexamination of the classical PKN model of hydraulic fracture. Transport in Porous Media, 81(2), 317-339. https://doi.org/10.1007/s11242-009-9403-4

Kusumastuti, I., Erfando, T., \& Hidayat, F. (2019). Effects of Various Steam Flooding Injection Patterns and Steam Quality to Recovery Factor. Journal of Earth Energy Engineering, 8(1), 33-39. https://doi.org/10.25299/jeee.2019.vol8(1).2909

Liu, P., Zhao, L., Luo, Z., Li, N., \& Xu, M. (2013, June). Predicting Productivity of Hydraulic Fracturing with Pre-Pad Acid. 47th U.S. Rock Mechanics/Geomechanics Symposium.

Melysa, R. (2016). Prediksi Kinerja Steamflood Dengan Metode Myhill-Stegemeier dan Gomaa di Area R Duri Steamflood (DSF). Journal of Earth Energy Engineering, 5(2), 44-56. https://doi.org/10.22549/jeee.v5i2.478

Montgomery, C. T., \& Smith, M. B. (2010). Hydraulic fracturing: History of an enduring technology. Journal of Petroleum Technology, 62(12), 26-32. https://doi.org/10.2118/1210-0026-jpt

Rahman, M. M., \& Rahman, M. K. (2010). A review of hydraulic fracture models and development of an improved pseudo-3D model for stimulating tight oil/gas sand. Energy Sources, Part A: Recovery, Utilization and Environmental Effects, 32(15), 1416-1436. 
https://doi.org/10.1080/15567030903060523

Wibowo. (2005). Diktat Kuliah Teknik Produksi II. Jurusan Teknik Perminyakan, Univeritas Pembangunan Nasional "Veteran" Yogyakarta, Indonesia.

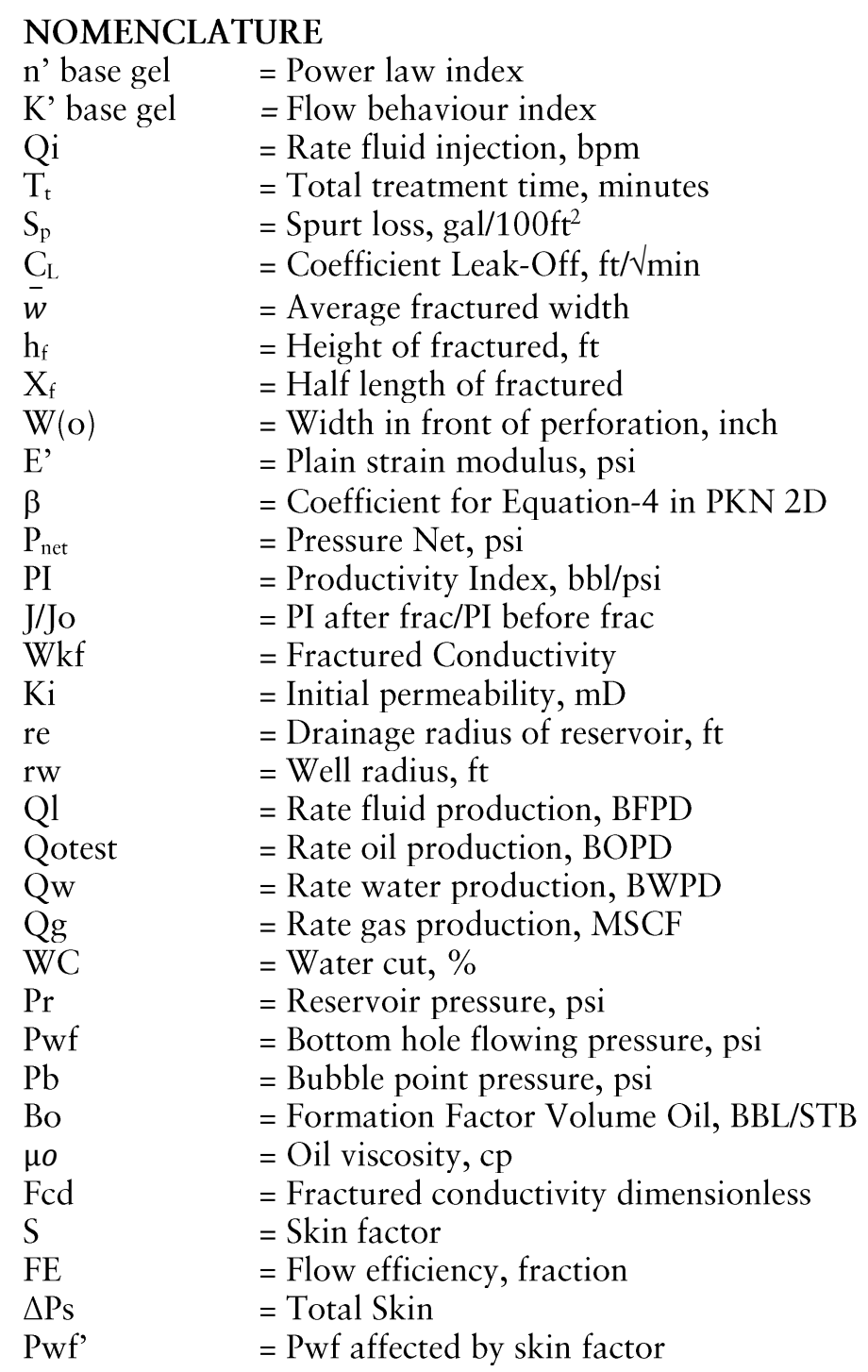

\section{APPENDIX}

Table 7. Final Pad Scenario for Main Fracturing

\begin{tabular}{cccccccccc}
\hline \multicolumn{10}{c}{ Job Execution } \\
\hline $\begin{array}{c}\text { Step } \\
\text { Name }\end{array}$ & $\begin{array}{c}\text { Step } \\
\text { Fluid } \\
\text { Name } \\
\text { (gal) }\end{array}$ & $\begin{array}{c}\text { Cum } \\
\text { Fluid } \\
\text { Vol } \\
(\text { gal })\end{array}$ & $\begin{array}{c}\text { Step } \\
\text { Slurry } \\
\text { Vol } \\
(\mathrm{bbl})\end{array}$ & $\begin{array}{c}\text { Cum } \\
\text { Slurry } \\
\text { Volume } \\
(\mathrm{bbl})\end{array}$ & $\begin{array}{c}\text { Step } \\
\text { Prop } \\
(\mathrm{lb})\end{array}$ & $\begin{array}{c}\text { Cum } \\
\text { Prop } \\
(\mathrm{lb})\end{array}$ & $\begin{array}{c}\text { Avg } \\
\text { Surface } \\
\text { Pressure } \\
(\mathrm{psig})\end{array}$ & $\begin{array}{c}\text { Step } \\
\text { Time } \\
(\mathrm{min})\end{array}$ & $\begin{array}{c}\text { Cum } \\
\text { Time } \\
(\mathrm{min})\end{array}$ \\
\hline PAD & 28140 & 28140 & 670 & 670 & 0 & 0 & 2320 & 37.2 & 37.2 \\
1 PPA & 2016 & 30156 & 49.1 & 719.1 & 1008 & 1008 & 2373 & 2.7 & 39.9 \\
2 PPA & 2184 & 32340 & 54.3 & 773.4 & 2184 & 3192 & 2371 & 3 & 42.9 \\
3 PPA & 2310 & 34650 & 59.8 & 833.2 & 4620 & 7812 & 2371 & 3.3 & 46.2 \\
4 PPA & 2900 & 37550 & 76.8 & 910 & 8700 & 16512 & 2383 & 4.3 & 50.5 \\
5 PPA & 3500 & 41050 & 95.7 & 1005.7 & 14000 & 30512 & 2431 & 5.3 & 55.8 \\
6 PPA & 3780 & 44830 & 106.7 & 1112.4 & 18900 & 49412 & 2600 & 5.9 & 61.7 \\
FLUSH & 2073 & 46903 & 49.3 & 1161.7 & 0 & 49412 & 2586 & 2.7 & 64.4 \\
\hline
\end{tabular}


An Integrated Analysis for Post Hydraulic Fracturing Production Forecast in Conventional Oil Sand Reservoir (Dedy Kristanto, IDM Saputra Jagadita)

Table 8. Fractured Geometry Data

\begin{tabular}{lcccc}
\hline Proppant & UoM & Pleliminary Design & Re-design & Post Job Estimated \\
Fracture Properties & & & & \\
\hline Model Used in Analysis & & P3D & P3D & P3D \\
Propped Fracture Half Length & $\mathrm{ft}$ & 158.4 & 267.4 & 263.1 \\
Fracture Height & $\mathrm{ft}$ & 125 & 102.7 & 107.8 \\
Average Propped Width & $\mathrm{in}$ & 0.214 & 0.123 & 0.11 \\
Fracture Conductivity & $\mathrm{md}-\mathrm{ft}$ & 10290 & 6908 & 6917 \\
Net Pressure & $\mathrm{psi}$ & 1370 & 1117 & 904 \\
\hline
\end{tabular}

Table 9. Zone Geomechanic Data

\begin{tabular}{|c|c|c|c|c|c|c|c|}
\hline \multicolumn{8}{|c|}{ Formation Mechanical Properties } \\
\hline Zone Name & $\begin{array}{c}\text { Top } \\
\text { TVD } \\
(\mathrm{ft})\end{array}$ & $\begin{array}{c}\text { Zone } \\
\text { Height } \\
\text { (ft) }\end{array}$ & $\begin{array}{c}\text { Frac } \\
\text { Grad. } \\
\text { (Psi/ft) }\end{array}$ & $\begin{array}{c}\text { Insitu } \\
\text { Stress } \\
\text { (psi) }\end{array}$ & $\begin{array}{l}\text { Young's } \\
\text { Modulus } \\
\text { (psi) }\end{array}$ & $\begin{array}{c}\text { Poisson's } \\
\text { Ratio }\end{array}$ & $\begin{array}{l}\text { Toughness } \\
\text { (psi.in0.5) }\end{array}$ \\
\hline $\begin{array}{c}\text { Clean- } \\
\text { Sandstone }\end{array}$ & 5165.4 & 8.4 & 0.701 & 3623 & $3.805 \mathrm{E}+6$ & 0.20 & 1200 \\
\hline $\begin{array}{l}\text { Clean- } \\
\text { Sandstone }\end{array}$ & 5173.8 & 5.6 & 0.713 & 3690 & $1.579 \mathrm{E}+6$ & 0.25 & 700 \\
\hline $\begin{array}{c}\text { Clean- } \\
\text { Sandstone }\end{array}$ & 5179.4 & 5.3 & 0.712 & 3691 & $1.729 \mathrm{E}+6$ & 0.25 & 700 \\
\hline $\begin{array}{l}\text { Clean- } \\
\text { Sandstone }\end{array}$ & 5184.7 & 4.7 & 0.727 & 3771 & $2.063 \mathrm{E}+6$ & 0.25 & 700 \\
\hline $\begin{array}{l}\text { Clean- } \\
\text { Sandstone }\end{array}$ & 5189.3 & 7.5 & 0.733 & 3808 & $2.479 \mathrm{E}+6$ & 0.25 & 700 \\
\hline $\begin{array}{c}\text { Clean- } \\
\text { Sandstone }\end{array}$ & 5195.8 & 4.5 & 9.762 & 3963 & $3.525 \mathrm{E}+6$ & 0.25 & 700 \\
\hline Shale & 5201.3 & 3.4 & 0.802 & 4174 & $3.230 \mathrm{E}+6$ & 0.35 & 1000 \\
\hline Shale & 5204.7 & 3.1 & 0.839 & 4366 & $4.494 \mathrm{E}+6$ & 0.35 & 1000 \\
\hline Shale & 5207.8 & 3.5 & 0.832 & 4334 & $4.494 \mathrm{E}+6$ & 0.35 & 1000 \\
\hline Shale & 5211.3 & 3.2 & 0.823 & 4291 & $4.494 \mathrm{E}+6$ & 0.35 & 1000 \\
\hline Shale & 5214.5 & 6.1 & 0.823 & 4162 & $2.994 \mathrm{E}+6$ & 0.35 & 1000 \\
\hline Shale & 5220.5 & 3.6 & 0.787 & 4108 & $2.163 \mathrm{E}+6$ & 0.35 & 100 \\
\hline Shale & 5224.1 & 3.7 & 0.788 & 4117 & $2.351 \mathrm{E}+6$ & 0.35 & 100 \\
\hline Shale & 5227.8 & 1. & 0.799 & 4179 & $3.026 \mathrm{E}+6$ & 0.35 & 1000 \\
\hline
\end{tabular}

Table 10. Fluid Behaviour Data

\begin{tabular}{ccc}
\hline Parameters & Type 1 & Type 2 \\
\hline Fluid Name & Brine & YF 130 HTD \\
CL $(\mathrm{ft} / \sqrt{ }$ min $)$ & $20 \mathrm{E}-2$ & $35 \mathrm{E}-4$ \\
Spurt $\left(\mathrm{gal} / 100 \mathrm{ft}^{2}\right)$ & 0.0 & 0.0 \\
Temperature $\left({ }^{\circ} \mathrm{F}\right)$ & 250 & 250 \\
Behaviour Index $\left(\mathrm{N}^{\prime}\right)$ & 0.2 & 0.4 \\
Consist Index $\left(\mathrm{K}^{\prime}\right)$ & $4.84 \mathrm{E}-6$ & $3.5 \mathrm{E}-1$ \\
\hline
\end{tabular}

Table 11. Value of $\beta^{4)}$

\begin{tabular}{cccccc}
\hline$\beta$ & $\begin{array}{c}\operatorname{Exp}\left(\beta^{2}\right) \operatorname{erfc} \beta+ \\
(2 \beta / \sqrt{\pi})-1\end{array}$ & $\beta$ & $\begin{array}{c}\operatorname{Exp}\left(\beta^{2}\right) \operatorname{erfc} \beta+ \\
(2 \beta / \sqrt{\pi})-1\end{array}$ & $\beta$ & $\begin{array}{c}\operatorname{Exp}\left(\beta^{2}\right) \operatorname{erfc} \beta+ \\
(2 \beta / \sqrt{ } \pi)-1\end{array}$ \\
\hline 0.00 & 0.00000 & 0.88 & 0.45571 & 3.30 & 2.88766 \\
0.02 & 0.00039 & 0.90 & 0.47207 & 3.40 & 2.99602 \\
0.04 & 0.00155 & 0.92 & 0.48858 & 3.50 & 3.10462 \\
0.06 & 0.00344 & 0.94 & 0.50523 & 3.60 & 3.21343 \\
0.08 & 0.00603 & 0.96 & 0.52201 & 3.70 & 3.32244 \\
0.10 & 0.00929 & 0.98 & 0.53892 & 3.80 & 3.43163 \\
0.12 & 0.01320 & 1.00 & 0.55596 & 3.90 & 3.54099 \\
0.14 & 0.01771 & 1.05 & 0.59910 & 4.00 & 3.65052 \\
0.16 & 0.02282 & 1.10 & 0.64295 & 4.10 & 3.76019 \\
0.18 & 0.02849 & 1.15 & 0.68746 & 4.20 & 3.87000 \\
0.20 & 0.03470 & 1.20 & 0.73259 & 4.30 & 3.97994 \\
0.22 & 0.04142 & 1.25 & 0.77830 & 4.40 & 4.09001 \\
0.24 & 0.04865 & 1.30 & 0.82454 & 4.50 & 4.20019 \\
0.26 & 0.05635 & 1.35 & 0.87127 & 4.60 & 4.31048 \\
0.28 & 0.06451 & 1.40 & 0.91847 & 4.70 & 4.42087 \\
0.30 & 0.07311 & 1.45 & 0.96611 & 4.80 & 4.53136
\end{tabular}


P a g e 17

\begin{tabular}{llllll}
0.32 & 0.08214 & 1.50 & 1.01415 & 4.90 & 4.64194 \\
0.34 & 0.09157 & 1.55 & 1.06258 & 5.00 & 4.75260 \\
0.36 & 0.10139 & 1.60 & 1.11136 & 5.20 & 4.97417 \\
0.38 & 0.11158 & 1.65 & 1.16048 & 5.40 & 5.19602 \\
0.40 & 0.12214 & 1.70 & 1.20991 & 5.60 & 5.41814 \\
0.42 & 0.13304 & 1.75 & 1.25964 & 5.80 & 5.64049 \\
0.44 & 0.14428 & 1.80 & 1.30964 & 6.00 & 5.86305 \\
0.46 & 0.15584 & 1.85 & 1.35991 & 6.20 & 6.08581 \\
0.48 & 0.16771 & 1.90 & 1.41043 & 6.40 & 6.30874 \\
0.50 & 0.17988 & 1.95 & 1.46118 & 6.60 & 6.53184 \\
0.52 & 0.19234 & 2.00 & 1.51215 & 6.80 & 6.75508 \\
0.54 & 0.20507 & 2.05 & 1.56334 & 7.00 & 6.97845 \\
0.56 & 0.21807 & 2.10 & 1.61472 & 7.20 & 7.20195 \\
0.58 & 0.23133 & 2.15 & 1.66628 & 7.40 & 7.42557 \\
0.60 & 0.24483 & 2.20 & 1.71803 & 7.60 & 7.64929 \\
0.62 & 0.25858 & 2.25 & 1.76994 & 7.80 & 7.87311 \\
0.64 & 0.27256 & 2.30 & 1.82201 & 8.00 & 8.09702 \\
0.66 & 0.28675 & 2.35 & 1.87424 & 8.20 & 8.32101 \\
0.68 & 0.30117 & 2.40 & 1.92661 & 8.40 & 8.54508 \\
0.70 & 0.31580 & 2.45 & 1.97912 & 8.60 & 8.76923 \\
0.72 & 0.33062 & 2.50 & 2.03175 & 8.80 & 8.99344 \\
0.74 & 0.34564 & 2.60 & 2.13740 & 9.00 & 9.21772 \\
0.76 & 0.36085 & 2.70 & 2.24350 & 9.20 & 9.44206 \\
0.78 & 0.37624 & 2.80 & 2.355001 & 9.40 & 9.66645 \\
0.80 & 0.39180 & 2.90 & 2.45690 & 9.60 & 9.89090 \\
0.82 & 0.40754 & 3.00 & 2.56414 & 9.80 & 10.11539 \\
0.84 & 0.42344 & 3.10 & 2.67169 & 10.00 & 10.33993 \\
0.86 & 0.43950 & 3.20 & 2.77954 & & \\
\hline & & For value $\beta>4, \exp \left(\Omega^{2}\right)$ erfc $\beta \approx(1 /(3 / \sqrt{ } \pi))$ & \\
\hline
\end{tabular}

Journal of Earth Energy Engineering

Vol. 10 No. 1, March 2021, pp 1-17

4.64194

5.19602

5.64049

6.30874

6.53184

6.75508

7.42557

8.09702

8.54508

8.76923

8.99344

9.66645

9.89090

10.11539

10.33993

Table 12. Trial Error PKN 2D Method

\begin{tabular}{|c|c|c|c|c|c|c|c|}
\hline Itr, m & $\mathrm{Xf}(\mathrm{itr}), \mathrm{m}$ & $\mathrm{w}(\mathrm{o}), \mathrm{m}$ & $\mathrm{w}, \mathrm{m}$ & $\mathrm{b}$ & $\exp (\mathrm{b} 2) \operatorname{erfc}(\mathrm{b})$ & $\mathrm{Xf}(\mathrm{itr}+1), \mathrm{m}$ & error \\
\hline 1 & 49.07 & 0.063212135 & 0.039697221 & 0.807998453 & 0.383753 & 77.2302114 & 28.1602114 \\
\hline 2 & 77.2302114 & 0.07432712 & 0.046677431 & 0.687169199 & 0.2911565 & 68.89834263 & $\begin{array}{c}- \\
8.331868769\end{array}$ \\
\hline 3 & 68.89834263 & 0.071357679 & 0.044812622 & 0.715764696 & 0.3092165 & 70.24871042 & 1.350367794 \\
\hline 4 & 70.24871042 & 0.071854055 & 0.045124346 & 0.710820114 & 0.305559 & 69.90067038 & $\begin{array}{c}- \\
0.348040046\end{array}$ \\
\hline 5 & 69.90067038 & 0.071726711 & 0.045044375 & 0.712082104 & 0.3065026 & 69.99226714 & 0.091596758 \\
\hline 6 & 69.99226714 & 0.071760265 & 0.045065446 & 0.71174915 & 0.30620272 & 69.95649736 & $\begin{array}{c}- \\
0.035769772\end{array}$ \\
\hline 7 & 69.95649736 & 0.071747165 & 0.04505722 & 0.711879102 & 0.306272213 & 69.95960056 & 0.003103194 \\
\hline 8 & 69.95705569 & 0.07174737 & 0.045057348 & 0.711877073 & 0.306259702 & 69.95694221 & $\begin{array}{c}- \\
0.000113486\end{array}$ \\
\hline 9 & 69.95671953 & 0.071747246 & 0.045057271 & 0.711878295 & 0.306259087 & 69.95668178 & $\begin{array}{c}-3.77483 \mathrm{E}- \\
05\end{array}$ \\
\hline 10 & 69.95671953 & 0.071747246 & 0.045057271 & 0.711878295 & 0.306259087 & 69.95668178 & $\begin{array}{c}-3.77483 \mathrm{E}- \\
05\end{array}$ \\
\hline
\end{tabular}

